\title{
The in-vitro evaluation of antibacterial, antifungal and cytotoxic properties of Marrubium vulgare L. essential oil grown in Tunisia
}

\author{
Zied Zarai ${ }^{1}$, Adel Kadri ${ }^{2}$, Ines Ben Chobba ${ }^{3}$, Riadh Ben Mansour ${ }^{4}$, Ahmed Bekir ${ }^{5}$, Hafedh Mejdoub ${ }^{6}$ and \\ Néji Gharsallah ${ }^{3}$
}

\begin{abstract}
Background: In order to validate its antiseptic and anticancer properties with respect to traditional uses, we have screened for the first time the antimicrobial activity of aerial parts of $M$. vulgare L. essential oil against different pathogenic microorganisms and the cytotoxic activity against HeLa cell lines.

Methods: The agar disk diffusion method was used to study the antibacterial activity of $M$. vulgare essential oil against 12 bacterial and 4 fungi strains. The disc diameters of zone of inhibition (DD), the minimum inhibitory concentrations (MIC) and the concentration inhibiting 50\% (I $\left.\mathrm{C}_{50}\right)$ were investigated to characterize the antimicrobial activities of this essential oil. The in vitro cytotoxicity of $M$. vulgare essential oil was examined using a modified MTT assay; the viability and the $\mathrm{IC}_{50}$ were used to evaluate this test.

Results: The antimicrobial activity of the essential oil was investigated in order to evaluate its efficacy against the different tested microorganisms. The present results results showed a significant activity against microorganisms especially Gram (+) bacteria with inhibition zones and minimal inhibitory concentration values in the range of 6.6-25.2 $\mathrm{mm}$ and 1120-2600 $\mathrm{mg} / \mathrm{ml}$, respectively, whereas Gram (-) bacteria exhibited a higher resistance. As far as the antifungal activity, among four strains tested, Botrytis cinerea exhibited the strongest activity with inhibition zones of $12.6 \mathrm{~mm}$. However, Fusarium solani, Penicillium digitatum and Aspergillus niger were less sensitive to $M$. vulgare essential oil. About the citotoxicity assay, this finding indicate the capability of this essential oil to inhibited the proliferation of HeLa cell lines under some conditions with $I C_{50}$ value of $0.258 \mu \mathrm{g} / \mathrm{ml}$.

Conclusion: This investigation showed that the M. vulgare essential oil has a potent antimicrobial activity against some Gram (+) pathogenic bacteria and Botrytis cinerea fungi. The present studies confirm the use of this essential oil as anticancer agent. Further research is required to evaluate the practical values of therapeutic applications.
\end{abstract}

Keywords: Antimicrobial, cytotoxicity, essential oil, Marrubium vulgare L., pathogenic microorganisms, HeLa cell lines

\section{Background}

The Lamiaceae plants was considered as one of the large plant families used as a framework to evaluate the occurrence of typical secondary metabolites [1]. The genus Marrubium comprises 10 species, which are found wild in many regions of Tunisia. Among them, Marrubium vulgare $\mathrm{L}$. is a perennial herb of the Labiatae family

\footnotetext{
* Correspondence: lukadel@yahoo.fr

${ }^{2}$ Laboratoire de Chimie des Substances Naturelles, Faculté des Sciences de Sfax, B.P. 1171, 3000 Sfax, University of Sfax, Tunisia

Full list of author information is available at the end of the article
}

which is commonly known as "horehound" in Europe, or "Marrubia" in Tunisia, is naturalized in North and South America, the latter and Western Asia. It possesses tonic, aromatic, stimulant, expectorant, diaphoretic and diuretic properties. It is helpful for bronchial asthma and nonproductive cough. It was formerly much esteemed in various uterine, visceral and hepatic affections and in phthisis [2]. In the Mediterranean region, $M$. vulgare is frequently used in folk medicine to cure a variety of diseases. The plant is reported to possess hypoglycemic [3], vasorelaxant [4], antihypertensive [5], analgesic [6,7],
Ciomed Central

() 2011 Zarai et al; licensee BioMed Central Ltd. This is an Open Access article distributed under the terms of the Creative Commons Attribution License (http://creativecommons.org/licenses/by/2.0), which permits unrestricted use, distribution, and reproduction in any medium, provided the original work is properly cited. 
anti-inflammatory [8], antioxidant activity $[9,10]$, antiedematogenic activity [11], and many other biological activities. In Tunisian folk medicine, it was used as hypotensive, hypoglycemic and cardiotonic.

Recently, a large number of essential (volatile) oils and their constituents have been investigated for their biological activity, notably antibacterial, antifungal, and antioxidant properties [12-14]. Essential oils and their components are gaining increasing interest as a natural alternative to synthetic drugs [15], particularly against microbial agents because of their relatively safe status wide acceptance by consumers and their exploitation for potential multipurpose functional use. The chemical compositions of M. vulgare essential oil from various origins have been the subject of many studies. The literature reveals the occurence of several chemotypes. From Lithuania, (Z)$\beta$-farnesene, $\beta$-caryophyllene, (E)-2-hexenal, $\alpha$-humulene and germacrene $\mathrm{D}$ were the main components of $M$. vulgare essential oil [16]. From Czech Republic, the main constituents of $M$. vulgare essential oil were $\beta$-caryophyllene and germacrene D [17]. From different region of Iran, the main constituants of $M$. vulgare essential tricyclene, $\beta$-pinene, bisabolol, $\beta$-elemone and isomenthon-8-thiol [18], $\beta$-bisabolene, 8 -cadinene and isocaryophyllene [19], and bisabolene, $\beta$-caryophyllene, germacrene $\mathrm{D}$ and $E$ - $\beta$ farnesene [20], caryophyllene oxide, $\beta$-caryophyllene and germacrene D [21].

The interest in plants with antimicrobial properties has been revived because of current problems associated with the use of antibiotics [22]. Therefore, essential oils and other naturally occurring antimicrobials are attractive to the food industry as well as imparting flavor [23]. More recently, the essential oil of this plant was advocated for their use as an antioxidant agent [10], but to the best of our knowledge, there are no reports on the antimicrobial properties and the cytotoxicity has been published.

Therefore, this paper was conducted to investigate for the first time the antimicrobial properties against clinical and pathogenic microorganisms and the cytotoxicity of $M$. vulgare essential oil grown in Tunisia.

\section{Methods}

\section{Chemicals, reagents and plant material}

Chemicals and reagents were supported by Prolabo (Paris, France) and Pharmacia (Uppsala, Swedeen). Plant materials (aerial parts) of $M$. vulgare $\mathrm{L}$. were grown in the vicinity of the village of Ouled Mnasser, with a latitude of $34.88\left(34^{\circ} 52^{\prime} 60 \mathrm{~N}\right)$ and a longitude of $9.13\left(9^{\circ} 7^{\prime} 60 \mathrm{E}\right)$ in Sidi Bouzid, Tunisia. The aerial parts of wild growing plant have been collected during the period of June-July 2009. The plant materials were confirmed by a senior A. bekir. Voucher specimens were deposited at ISET, Sfax (Département de Génie des procédés) as Bekir 520.
Distillation of essential oil and GC/MS analysis conditions The fresh aerial parts of $M$. vulgare (300 g) were hydrodistilled using a Clevenger-type apparatus to recover the essential oils for $4 \mathrm{~h}$. The distilled essential oils were dried over anhydrous sodium sulfate, filtered and stored at $+4^{\circ} \mathrm{C}$.

The essential oil was analyzed using an Agilent-Technologies $6890 \mathrm{~N}$ Network GC system equipped with a flame ionization detector and HP-5MS capillary column (30 m $\times 0.25 \mathrm{~mm}$, film thickness $0.25 \mu \mathrm{m}$; Agilent-Technologies, Little Falls, CA, USA). The injector and detector temperatures were set at 250 and $280^{\circ} \mathrm{C}$, respectively. The column temperature was programmed from 35 to $250^{\circ} \mathrm{C}$ at a rate of $5^{\circ} \mathrm{C} / \mathrm{min}$, with the lower and upper temperatures being held for 3 and $10 \mathrm{~min}$, respectively. The flow rate of the carrier gas (helium) was $1.0 \mathrm{ml} / \mathrm{min}$. A sample of $1.0 \mu \mathrm{l}$ was injected, using split mode (split ratio, 1:100). All quantifications were carried out using a built-in datahandling program provided by the manufacturer of the gas chromatograph. The composition was reported as a relative percentage of the total peak area. The identification of the essential oil constituents was based on a comparison of their retention times to $n$-alkanes, compared to published data and spectra of authentic compounds. Compounds were further identified and authenticated using their mass spectra compared to the Wiley version 7.0 library.

\section{Antimicrobial activity assay Microbial strain}

The essential oil of $M$. vulgare was individually tested against a panel of microorganisms (Table 1). The antimicrobial activities of essential oil were determined against sixteen of human-pathogenic microbial strains. The bacteria and fungi used were selected because they have implicated with skin, oral and intestinal tract of man. Twelve species of bacteria and four species of fungi as shown in Table 1 were used in this study.

$\begin{aligned} & \text { Table } \mathbf{1} \text { Pathogenic bacteria and fungi used for the } \\
& \text { antimicrobial assay }\end{aligned}$
\begin{tabular}{ll} 
Bacteria & \\
\hline Staphylococcus aureus 1327 & Staphylococcus epidermidis \\
Micrococcus luteus & Enterococcus faecalis \\
Enterobacter cloacae & Staphylococcus aureus 25923 \\
Bacillus subtilis & Bacillus cereus \\
Pseudomonas aeruginosa 27853 & Klebsielle pneumoniae WHO24 \\
Escherchia coli 25922 & \\
Fungi & \\
\hline Botrytis cinerea & Fusarium solan \\
Penicillium digitatum & Aspergillus niger \\
\hline
\end{tabular}




\section{Agar diffusion method}

The agar diffusion method was employed for the determination of antibacterial activities of $M$. vulgare essential oil according to the method described by Berghe and Vlietinck (1991) [24]. The essential oil extracts were dissolved in $100 \%$ ethanol to a final concentration of $10 \mathrm{mg} / \mathrm{ml}$ and sterilized by filtration trough $0.22 \mu \mathrm{m}$ Nylon membrane filter. The bacterial strains were cultured in a nutriment broth for 24 hours. Then, $200 \mu$ of each suspension bacteria $\left(10^{6} \mathrm{CFU}\right.$ estimated by absorbance at $\left.600 \mathrm{~nm}\right)$ was spread on Luria Broth agar. Bores were made by using a sterile borer and were loaded with $10 \mu \mathrm{l}$ of each sample extract. Ethanol was used as negative control and ampicillin $(10 \mu \mathrm{g} /$ puit $)$ as positive reference standard. All the plates were incubated at $37^{\circ} \mathrm{C}$ for 24 hours. Antibacterial activity was evaluated by measuring the zone of inhibition in millimetres. All experiments were done in triplicates.

\section{Determination of the minimal inhibitory concentration (MIC)}

The minimal inhibitory concentration (MIC) values, which represent the lowest essential oil concentration that completely inhibits the growth of microorganisms, were determined by a micro-well dilution method [25]. The inoculum of each bacterium was prepared and the suspensions were adjusted to $10^{6} \mathrm{CFU} / \mathrm{ml}$. All the extracts were dissolved in $100 \%$ ethanol and then dilutions series were prepared in a 96-well plate. Each well of the microplate included $40 \mu \mathrm{l}$ of the growth medium, $10 \mu \mathrm{l}$ of inoculums and $50 \mu \mathrm{l}$ of the diluted sample extract. The ampicillin and ethanol are used as positive and negative controls, respectively. The plates were then covered with the sterile plate and incubated at $37^{\circ} \mathrm{C}$ for $24 \mathrm{~h}$. After that, $40 \mu \mathrm{l}$ of 3- (4, 5-dimethyl-thiazol-2-yl)2,5-diphenyl-tetrazolium bromide (MTT) at a final concentration $0.5 \mathrm{mg} / \mathrm{ml}$ freshly prepared in water was added to each well and incubated for $30 \mathrm{~min}$. The change to red colour indicated that the bacteria were biologically active. The MIC was taken to the well, where no change of colour of MTT was observed. The MIC values were done in triplicate.

\section{Antibacterial assay disc-diffusion method}

An antibacterial activity of the essential oils was screened against eight human pathogenic bacteria. The inhibitory effect on bacterial growth was determined using agardisc diffusion assay [26,27]. The bacterial cultures were first grown on Muller Hinton agar $(\mathrm{MH})$ plates at $37^{\circ} \mathrm{C}$ for 18 to $24 \mathrm{~h}$ prior to seeding onto the nutrient agar. One or several colonies of the respective bacteria were transferred into API suspension medium (bioMerieux) and adjusted to $0.5 \mathrm{McF}$ arland turbidity standards with a Densimat (bioMerieux) [28,29]. The inocula of the respective bacteria were streaked into $\mathrm{MH}$ agar plates using a sterile swab and were then dried at $37^{\circ} \mathrm{C}$ during $15 \mathrm{~min}$. A sterile filter disc having $6 \mathrm{~mm}$ of diameter was placed at the surface of $\mathrm{MH}$ agar and $5 \mu \mathrm{l}$ of the essential oil was dropped onto each Whatman paper disc [30]. The treated Petri dishes were incubated at $37^{\circ} \mathrm{C}$ for 18 to $24 \mathrm{~h}$. The antibacterial activity was evaluated by measuring the clear zone surrounding the Whatman paper. Standard discs of the antibiotic ampicillin were applied as a positive antibacterial controls.

\section{Antibacterial assay dilution method}

The minimal inhibitory concentration (MIC) of essential oil was determined using the Mueller Hinton broth (MHB) dilution method [31]. All tests were performed in MHB supplemented with ethanol 5\% [32]. Bacterial strains were cultured overnight in $\mathrm{MHB}$ at $37^{\circ} \mathrm{C}$. Tubes of $\mathrm{MHB}$ containing various concentrations of oils were inoculated with $10 \mu \mathrm{l}$ bacterial inoculums adjusted to $10^{6} \mathrm{CFU} / \mathrm{ml}$. They were incubated under shaking conditions $(100-120 \mathrm{rpm})$ at $37^{\circ} \mathrm{C}$ for $24 \mathrm{~h}[33,34]$. Control tubes without tested samples were essayed simultaneously. The essays were performed in triplicate. The MIC was defined as the lowest concentration preventing visible growth $[35,36]$.

\section{Antifungal assay disc-diffusion method}

The biological activity against yeasts was determined by employing disc agar diffusion method using Sabouraud Dextrose agar [37]. An aliquot $(5 \mu \mathrm{l})$ of the oil was deposited on sterile paper discs (6 $\mathrm{mm}$ diameter) which were subsequently placed in the centre of the inoculated Petri dishes. After an incubation period of the $24 \mathrm{~h}$ at $30^{\circ} \mathrm{C}$, the inhibitory activity was compared to that of commercial cycloheximide at a concentration of $10 \mathrm{mg} / \mathrm{ml}$.

\section{Cell lines and culture condition}

HeLa cells (cervical cancer line, adherent) were used to investigate the cytotoxicity effect of essential oil. This cell line were grown in RPMI 1640 medium (Gibco) supplemented with $10 \%(\mathrm{v} / \mathrm{v})$ foetal calf serum (FCS) and $2 \mathrm{mM}$ L-glutamin in tissue culture flasks (Nunc). They were passed twice a week and kept at $37^{\circ} \mathrm{C}$ in a humidified atmosphere of $95 \%$ air and $5 \% \mathrm{CO}_{2}$.

\section{MTT test}

The proliferation rates of HeLa cells after treatment with essential oils were determined by the colorimetric 3-(4,5dimethylthiazol-2-yl)-2,5-diphenyl tetrazolium bromide (MTT) assay. The yellow compound MTT is reduced by mitochondrial dehydrogenases to the water-insoluble blue compound formazan, depending on the viability of cells.

HeLa cells $\left(4 \times 10^{4}\right.$ in each well) were incubated in 96well plates for 24 hours in the presence or absence of essential oil. Twenty microlitres MTT solution (Sigma) (5 mg mL $\mathrm{mL}^{-1}$ in $\mathrm{PBS}$ ) were added to each well. The plate was incubated for $4 \mathrm{~h}$ at $37^{\circ} \mathrm{C}$ in a $\mathrm{CO}_{2}$-incubator. One hundred and eighty microlitres of medium was removed 
from every well without disturbing the cell clusters. A $180 \mu \mathrm{l}$ methanol/DMSO solution (50:50) was added to each well, and the preparations were mixed thoroughly on a plate shaker with the cell containing formazan crystals. After all of the crystals were dissolved, the A570 values were determined with a microplate reader (ELx 800).

\section{Results and Discussion \\ Antimicrobial assays}

The antimicrobial activities of $M$. vulgare essential oil against microorganisms examined in the present study and their potency were qualitatively and quantitatively assessed by the presence or absence of inhibition zones and zone diameter (DD), the medium inhibitory concentration $\left(\mathrm{IC}_{50}\right)$ and the minimal inhibitory concentration (MIC) values. This essential oil displayed varied antibacterial and antifungal activities across the studied pathogens. As can be seen from Table 2, essential oil inhibited the growth of bacterial strains produced a zone diameter of inhibition from 6.6 to $25.2 \mathrm{~mm}$ for Gram (+) bacteria, along with $\mathrm{IC}_{50}$ and MIC values ranging from $560-1100 \mu \mathrm{g} / \mathrm{ml}$ and $1120-2600 \mu \mathrm{g} / \mathrm{ml}$, respectively. Whereas, for Gram (-) bacteria, no antimicrobial activities of essential oil tested against all strains (Pseudomonas aeruginosa 27853, Klebsielle pneumoniae WHO24, Escherichia coli 25922 and Salmonella) has been revealed. Among Gram (+) bacteria, the strongest activity of $M$. vulgare essential oil was observed against Staphylococcus epidermidis (25.2 mm) followed by Staphylococcus aureus 25923 (18 mm), Enterobacter cloacae $(13.8 \mathrm{~mm})$, Bacillus subtilis $(13.2 \mathrm{~mm})$, Micrococcus luteus $(12 \mathrm{~mm})$ and Staphylococcus aureus 1327 (12 mm). However, Enterococcus faecalis (9.6 mm) and Bacillus cereus $(6.6 \mathrm{~mm})$ exhibited moderate to weak activities, respectively.

For the fungi strains, the disc diameter zones of inhibition ranged from 6.4-12.6 mm, along with $\mathrm{IC}_{50}$ and $\mathrm{MIC}$ values ranging from $2190-3000 \mu \mathrm{g} / \mathrm{ml}$ and $1100-1180 \mu \mathrm{g} / \mathrm{ml}$, respectively. The maximal inhibition zones was obtained for Botrytis cinerea, however Fusarium solani, Penicillium digitatum and Aspergillus niger exhibited weak activity. Our results suggest that Gram (+) bacteria are more sensitive to the M. vulgare essential than Gram (-) bacteria. This was consistent with the previous studies on other spices and herbs $[38,39]$. This generally higher resistance among Gram (-) bacteria could be ascribed to the presence of their

Table 2 Antibacterial and antifungal activity of the essential oil of $M$. vulgare using agar disc diffusion, $I_{50}$ and minimal inhibition concentration (MIC)

\begin{tabular}{|c|c|c|c|c|}
\hline Strains & $\mathrm{DD}^{\mathrm{a}}$ & $I C_{50}{ }^{b}$ & MIC $^{\mathrm{C}}$ & ${D D^{d}}^{d}$ \\
\hline \multicolumn{5}{|l|}{ Bacterial strains Gram (+) } \\
\hline Staphylococcus aureus & $12.0 \pm 0.5$ & $2500 \pm 50$ & $>1100.00$ & $20 \pm 0.5$ \\
\hline Staphylococcus epidermidis & $25.2 \pm 0.3$ & $2200 \pm 50$ & $>590.00$ & $26 \pm 0.5$ \\
\hline Micrococcus luteus & $12.0 \pm 0.5$ & $1120 \pm 50$ & $>560.00$ & $20 \pm 1.5$ \\
\hline Enterococcus faecalis & $9.6 \pm 1.0$ & $1140 \pm 10$ & $>680.00$ & $25 \pm 1.0$ \\
\hline Enterobacter cloacae & $13.8 \pm 0.6$ & $1500 \pm 90$ & $>670.00$ & $21 \pm 1.4$ \\
\hline Staphylococcus aureus 25923 & $18 \pm 1.0$ & $2600 \pm 80$ & $>1150.00$ & $24 \pm 0.5$ \\
\hline Bacillus subtilis & $13.2 \pm 1.0$ & $2130 \pm 50$ & $>890.00$ & $26 \pm 0.6$ \\
\hline Bacillus cereus & $6.6 \pm 0.4$ & $2113 \pm 40$ & $>950.00$ & $21 \pm 1.0$ \\
\hline \multicolumn{5}{|l|}{ Bacterial strains Gram (-) } \\
\hline Botrytis cinerea & NS & NS & NS & $21 \pm 0.5$ \\
\hline Pseudomonas aeruginosa 27853 & NS & NS & NS & $20 \pm 1.0$ \\
\hline Klebsielle pneumoniae WHO24 & NS & NS & NS & $21 \pm 0.9$ \\
\hline Escherchia coli 25922 & NS & NS & NS & $22 \pm 0.8$ \\
\hline Salmonella & NS & NS & NS & $29 \pm 1.0$ \\
\hline \multicolumn{5}{|l|}{ Fungal strains } \\
\hline Botrytis cinerea & $12.6 \pm 0.5$ & $2190 \pm 12$ & $>1100.00$ & $29 \pm 1.0$ \\
\hline Fusarium solani & $6.9 \pm 0.5$ & $3220 \pm 20$ & $>1190.00$ & $28 \pm 0.6$ \\
\hline Penicillium digitatum & $6.6 \pm 0.4$ & $3200 \pm 15$ & $>1120.00$ & $21 \pm 0.9$ \\
\hline Aspergillus. niger & $6.4 \pm 0.0$ & $3000 \pm 50$ & $>1180.00$ & $30 \pm 0.5$ \\
\hline
\end{tabular}

Results are means of three different experiments,

${ }^{a}$ DD: Disc Diameter of inhibition (halo size) in (mm), E. oil $100 \mu \mathrm{g} / \mathrm{disc}$,

${ }^{b}$ MIC: minimum inhibitory concentration $(\mu \mathrm{g} / \mathrm{ml})$,

${ }^{\mathrm{C}} \mathrm{C}_{50}$ : $50 \%$ inhibition concentration $(\mu \mathrm{g} / \mathrm{ml})$,

${ }^{d}$ DD: Disc Diameter of inhibition zone of ampicillin $(10 \mu \mathrm{g} / \mathrm{disc})$ and cycloheximide $(10 \mu \mathrm{g} / \mathrm{disc})$, were used as positive controls for bacteria and fungi, respectively,

NS: not sensitive. 
outer membrane, surrounding the cell wall, which restricts diffusion of hydrophobic compounds through its lipopolysaccharide covering. The absence of this barrier in Gram (+) bacteria allows the direct contact of the essential oil's hydrophobic constituents with the phospholipids bilayer of the cell membrane, causing either an increase of ion permeability and leakage of vital intracellular constituents, or impairment of the bacterial enzyme systems. Differences in MIC values of bacteria may be related to the differential susceptibility of bacterial cell wall, which is the functional barrier to minor differences present in the outer membrane in the cell wall composition [40]. The highest sensitivity of Staphylococcus epidermidis and Staphylococcus aureus may be due to its cell wall structure and outer membrane.

It is most likely that numerous components of the essential oils play a crucial role in defining the features of oils, lipophilic or hydrophilic attraction and fixation on cell wall and membranes, and cellular distribution [41]. This feature is very important because, depending on their component, the distribution of the oil in the cell determines the different types of biological activities such as antibacterial, antifungal and cytotoxicity. As reported previously [10], the $M$. vulgare essential oils isolated by hydrodistillation from the aerial parts was analyzed by HP-5MS column. The general chemical composition of the essential oil, the percentage contents, and retention indices of the components are given in Table 3. Thirty four components could be identified in the oil $(100 \%$ of the total oil). The essential oil is constituted mainly by approximately equal amounts of oxygenated monoterpenes (40.02\%) and sesquiterpenes hydrocarbons $(42.70 \%)$. The major components were $\gamma$-eudesmol $(11,93 \%)$, followed by $\beta$-citronellol $(9,90 \%)$, Citronellyl formate $(9,50 \%)$ and germacrene $\mathrm{D}(9,37 \%)$. When compared with previous studies [16-21], our study showed that this essential oil possessed an original composition with the main component of $\gamma$-eudesmol (11.93\%), which is not observed elsewhere.

The antimicrobial properties of essential oils from aerial part of $M$. vulgare are suspected to be associated, in part with their high contents of oxygenated compounds (46.21\%). Several researchers also report mono- and sesquiterpenoids as the major components of essential oils which are phenolic in nature $[42,43]$. It is therefore reasonable to assume that their antimicrobial activity might be related to the abundance of phenolic compounds. Referring to the literature, the antimicrobial activity of the tested essential oil can be related to the contribution of the mixture between major ( $\gamma$-eudesmol, $\beta$-citronellol, citronellyl formate and germacrene D) and minor (camphene, borneol) [10] constituents, which known to have efficient antimicrobial properties [44,45]. In addition, germacrene-D is known to have a strong effect on insect behavior [46] and has significant antibacterial and antifungal activities [47].
Therefore, Essential oils always represent a complex mixture of different chemical components, thus it is very difficult to reduce the antibacterial effect of the total oil to a few active principles.

Compared to the positive control, ampicillin (belonging to the penicillin group of beta-lactam antibiotics is able to penetrate Gram positive and some Gram negative bacteria) and cycloheximide (generally used only in in vitro research applications as a fungicide, and is not suitable for human use as a therapeutic compound) were found to possess lower activity than the tested essential oil. We explain this by the fact, that pure component, such as antibiotics give a more potent antimicrobial activity when compared to a complex mixture of components such as essential oils.

\section{Cytotoxicity assays}

The effect of different concentrations (3.91-3000 $\mu \mathrm{g} / \mathrm{ml})$, of $M$. vulgare essential oil on HeLa cell lines were studied. As depicted in Table 4, they significantly decreased the viability of HeLa in a dose dependent manner. For a concentration up to $250 \mu \mathrm{g} / \mathrm{ml}$, essential oil destructed HeLa cells by $27 \%$, however for a concentration higher than $500 \mu \mathrm{g} / \mathrm{ml}$, all HeLa cells were destructed. At lower doses, the oil was tolerated by the cells and its $\mathrm{IC}_{50}$ (the concentration of the tested oil required to reduce the cell survival fraction to $50 \%$ of the control) was $0.258 \mu \mathrm{g} / \mathrm{ml}$. The volatile oil displayed an excellent cytotoxic effect towards the human tumor cell line. This makes the tested oil certainly deserve some further investigation. Referring to the literature, the cytotoxicity of the tested essential oils may be due to the presence of some monoterpenes and sesquiterpenes including $\alpha$-Humulene [48] and isoprenoids including geraniol [49]. These compounds were reported to be active against the tumor cell lines, but in our oil, they exist in small amount [10]. Although, the presence of germacrene D in a good amount can enhances the cytoxicity of the tested oil. This results was confirmed by Setzer et al., who reported that germacrene D has exhibited a 7 -fold stronger cytotoxic activity against the $\mathrm{Hs} 578 \mathrm{~T}$ cell line in comparison with $\alpha$-pinene and limonene and a 6-fold stronger action against $\mathrm{Hs} 578 \mathrm{~T}$ and Hep-G2 than 1,8-cineole, linalool, 4-terpineol and $\alpha$-terpineol [50]. Some reports support the relationship of cytotoxicity with antioxidant activity [51]. So the antioxidant activity of $M$. vulgare essential oil might contribute to its cytotoxic activity [45]. Finally, we noted that the synergistic effects of these active chemicals with other constituents of the essential oil should be taken into consideration. This study also justifies and reinforces the use of this plant on traditional medicine. Although all in vitro experiments hold limitations with regards to possible in vivo efficacy. The results of this study are very promising as it will serve as a data base for researchers in these kinds of studies for 
Table 3 Chemical composition, retention indices and percentage composition of the M. vulgare essential oil

\begin{tabular}{|c|c|c|c|c|}
\hline $\mathbf{N}^{\circ}$ & Compound & RI & $\%$ & Identification \\
\hline 1 & $\mathrm{~N}$-trimethylsilyl trifluoroacetamide & 764 & 2.35 & MS, RI \\
\hline 2 & $\mathrm{~N}, \mathrm{~N}$-bis trimethylsilyl trifluoroacetamide & 857 & 0.97 & $M S, R I$ \\
\hline 3 & $\alpha$-pinene & 932 & 1.16 & MS, RI \\
\hline 4 & Camphene & 948 & 0.49 & $M S, R I$ \\
\hline 5 & 1,8-Cineole & 1044 & 3.72 & $M S, R I$ \\
\hline 6 & $\alpha$-thujone & 1131 & 2.29 & $M S, R I$ \\
\hline 7 & 1-Vinylcyclohexane & 1143 & 0.75 & MS, RI \\
\hline 8 & Camphor & 1174 & 1,03 & $M S, R I$ \\
\hline 9 & Iso menthone & 1197 & 0.57 & $\mathrm{MS}, \mathrm{Rl}$ \\
\hline 10 & Borneol & 1199 & 0.61 & $M S, R I$ \\
\hline 11 & $\beta$-citronellol & 1266 & 9.90 & $M S, R I$ \\
\hline 12 & Geraniol & 1295 & 2.74 & $\mathrm{MS}, \mathrm{RI}$ \\
\hline 13 & Citronellyl formate & 1315 & 9.50 & $M S, R I$ \\
\hline 14 & Geranyl formate & 1344 & 6.25 & MS, RI \\
\hline 15 & $\alpha$-copaene & 1419 & 1.37 & $M S, R I$ \\
\hline 16 & $\beta$-Bourbonene & 1429 & 1.96 & $M S, R I$ \\
\hline 17 & trans-caryophyllene & 1462 & 2.15 & $M S, R I$ \\
\hline 18 & $\alpha$-Muurolene & 1484 & 0.63 & MS, RI \\
\hline 19 & $\alpha$-amorphene & 1490 & 0.81 & $M S, R I$ \\
\hline 20 & $\alpha$-Humulene & 1495 & 0.68 & $M S, R I$ \\
\hline 21 & Neoalloocimene & 1502 & 0.91 & $\mathrm{MS}, \mathrm{RI}$ \\
\hline 22 & neryl acetate & 1512 & 3.41 & $M S, R I$ \\
\hline 23 & Germacrene-D & 1521 & 9.37 & $M S, R I$ \\
\hline 24 & Ledene & 1534 & 5.35 & MS, RI \\
\hline 25 & $\beta$-bisabolene & 1544 & 0.86 & MS, RI \\
\hline 26 & $\delta$-cadinene & 1559 & 3.30 & MS, RI \\
\hline 27 & $\alpha$-agarofuran & 1581 & 0.42 & $M S, R I$ \\
\hline 28 & Furan-2-one, 4-phenyltetrahydro & 1616 & 1.44 & $M S, R I$ \\
\hline 29 & $\gamma$-Eudesmol & 1647 & 11.93 & MS, Rl \\
\hline 30 & $\beta$-Cubebene & 1674 & 1.52 & $M S, R I$ \\
\hline 31 & Citronellyl butanoate & 1682 & 0.66 & $\mathrm{MS}, \mathrm{RI}$ \\
\hline 32 & Geranyl tiglate & 1712 & 5.53 & $M S, R I$ \\
\hline 33 & Cyclononasiloxane, octadecamethyl & 2198 & 3.08 & MS, RI \\
\hline 34 & Eicosamethylcyclodecasiloxane & 2264 & 2.29 & $\mathrm{MS}, \mathrm{Rl}$ \\
\hline \multicolumn{2}{|c|}{ Total identification } & & 100 & \\
\hline \multicolumn{2}{|c|}{ Yield (g/100 g dry weight) } & & 00.34 & \\
\hline \multicolumn{2}{|c|}{ Hydrocarbon monoterpenes } & & 01.65 & \\
\hline \multicolumn{2}{|c|}{ Oxygenated monoterpenes } & & 40.02 & \\
\hline \multicolumn{2}{|c|}{ Hydrocarbon sesquiterpenes } & & 42.70 & \\
\hline \multicolumn{2}{|c|}{ Oxygenated sesquiterpene } & & 06.19 & \\
\hline
\end{tabular}

indicating which essential oils and plant oils may be useful for specific medical conditions. Furthermore, it is still necessary to investigate in vivo bioactivity and cytoxicity of the oil, to explore in more depth its potential beneficial use in diseases and infections caused by microbes.

\section{Conclusion}

In conclusion, our study can be considered as the first report on the antimicrobial and cytotoxic properties of
M. vulgare volatile oil. The in vitro antimicrobial activity of the obtained may well be due to the presence of synergy, antagonism or additive effects of the tested major components of the oils, which possess various potency of activity. The results of the cytotoxic activity against HeLa cell lines in this study are very promising with regards to possible antineoplastic chemotherapy and form a very sound basis for future research. Our results are a contribution to a better valorization of this 
Table 4 Cytotoxic activity of $M$. vulgare essential oil determined by the MTT assay

\begin{tabular}{ccc}
\hline Oil $(\boldsymbol{\mu} \mathbf{g} / \mathbf{m l})$ & Mean $^{\text {OD }_{\mathbf{5 7 0}}(\mathbf{n m})}$ & \% Viable HeLa cell line \\
\hline 0 & 0.971 & 100.00 \\
3.91 & 0.836 & 86.10 \\
7.81 & 0.815 & 83.93 \\
15.63 & 0.798 & 82.18 \\
31.25 & 0.780 & 80.94 \\
62.50 & 0.756 & 77.85 \\
125 & 0.717 & 73.84 \\
250 & 0.707 & 72.81 \\
500 & 0.015 & 01.54 \\
1000 & 0.031 & 00.31 \\
3000 & 0.023 & 00.21 \\
\hline
\end{tabular}

medicinal plant. Several other biological tests will be worthwhile to search for more eventual activities of this plant to characterize active principles, and assess toxicity by laboratory assays.

\begin{abstract}
Author details
'Laboratoire de Biochimie et de Génie Enzymatique des Lipases, ENIS, BPW, 1173 Sfax, University of Sfax, Tunisia. ${ }^{2}$ Laboratoire de Chimie des Substances Naturelles, Faculté des Sciences de Sfax, B.P. 1171, 3000 Sfax, University of Sfax, Tunisia. ${ }^{3}$ Laboratoire de Microbiologie Alimentaire, Faculté des sciences de Sfax, B.P. 1171, 3000 Sfax, University of Sfax Tunisia. ${ }^{4}$ Unité de recherche Biotechnologie et pathologies, Institut Supérieur de Biotechnologie de Sfax, University of Sfax, Tunisia. ${ }^{5}$ Département de Génie des procédés, ISET Sfax, Km 2,5 Rte de Mahdia, 3099 Sfax, University of Sfax, Tunisia. 'Laboratoire de Biochimie, Faculté des sciences de Sfax, B.P. 1171, 3000 Sfax, University of Sfax, Tunisia.
\end{abstract}

\section{Authors' contributions}

$\mathrm{ZZ}, \mathrm{AK}, \mathrm{IBC}$ and RBM carried out the experimental part such as extraction, antibacterial, antifungal and cytotoxicity assays. AB contribute to the analysis of the results. HM and NG supervised the work and corrected the manuscript. Authors read and approved the final manuscript.

\section{Competing interests}

The authors declare that they have no competing interests.

Received: 23 August 2011 Accepted: 21 September 2011 Published: 21 September 2011

\section{References}

1. Wink M: Evolution of secondary metabolites from an ecological and molecular phylogenetic perspective. Phytochemistry 2003, 64:3-19.

2. Chopra RN, Nayer SL, Chopra IC: Glossary of Indian Medicinal Plants, CSIR, V ed. New Delhi. 1956, 12:157.

3. Roman RR, Aharcon AF, Lara LA, Flores SJL: Hypoglycemic effect of plants used in Mexico as antidiabetics. Arch Med Res 1992, 23(1):59-64.

4. El-Bardai S, Morel N, Wibo M, Fabre N, Llabres G, Lyoussi B, Quetin L: The vasorelaxant activity of marrubenol and marrubiin from Marrubium vulgare. Plant Med 2003, 69(1):75-77.

5. El-Bardai S, Lyoussi B, Wibo M, Morel N: Comparative Study of the antihypertensive activity of Marrubium Vulgare and of the dihydropyridine calcium antagonist amlodipine in spontaneously hypertensive rat. Clin Exp Hyprtens 2004, 26(6):465-474.

6. DeSouza MM, DeJesus RAP, Cechinel-Filho V, Schlemper V: Analgesic profile of hydroalcoholic extract obtained from Marrubium vulgare. Phytomed 1998, 5(2):103-107.
7. Sahpaz S, Garbacki N, Tits M, Bailleul F: Isolation and pharmacological activity of phenylpropanoid esters from Marrubium vulgare. J Ethnopharmacol 2002, 79(3):389-392.

8. Schlemper V, Ribas A, Nicolau M, Cechinel-Filho V: Antispasmodic effects of hydroalcoolic extract of Marrubium vulgare on isolated tissues. Phytomedicine 1996, , 3: 211-216.

9. Weel KCG, Venskutonis PR, Pukalskas A, Gruzdiene D, Linssen JPH: Antioxidant activity of horehound (Marrubium vulgare) grown in Lithuania. Fett/Lipid 1999, 101(10):395-400.

10. Kadri A, Zarai Z, Bekir A, Gharsallah N, Damak M, Gdoura R: Chemical composition and antioxidant activity of Marrubium vulgare L. essential oil from Tunisia. African Journal of biotechnolgy 2011, 10(198):3908-3914.

11. Stulzer HK, Tagliari MP, Zampirolo JA, Cechinel-Filho V, Schlemper V: Antioedematogenic effect of marrubiin obtained from Marrubium vulgare. J Ethnopharmacol 2006, 108(3):379-392.

12. Baratta MT, Dorman HJD, Deans SG, Figueiredo AC, Barroso JG, Ruberto G: Antimicrobial and antioxidant properties of some commercial essential oils. Flav Fragr J 1998, 13:235-44.

13. Cosentino S, Tuberoso CIG, Pisano B, Satta M, Mascia V, Arzedi E Palmas F: In vitro antimicrobial activity and chemical composition of Sardinian Thymus essential oils. Letters in Applied Microbiology 1999, 29:130-135.

14. Bounatirou S, Smiti S, Miguel MG, Faleiro L, Rejeb MN, Neffati M, Costa MM, Figueiredo AC, Barroso JG, Pedro LG: Chemical composition, antioxidant and antibacterial activities of the essential oils isolated from Tunisian Thymus capitatus Hoff. Et Link. Food Chem 2007, 105:146-155.

15. Fabio A, Cermelli C, Fabio G, Nicoletti P, Quaglio P: Screening of the antibacterial effects of variety of essential oils on microorganisms responsible for respiratory infections. Phytother Res 2007, 21:374-377.

16. Weel KCG, Venskutonis PR, Pukalskas A, Gruzdiene D, Linssen JPH: Antioxidant activity of horehound (Marrubium vulgare) grown in Lithuania. Fett/Lipid 1999, 101(10):395-400.

17. Nagy M, Svajdlenka E: Comparison of Essential Oils from Marrubium vulgare L. and M. peregrinum L. J Essent Oil Res 1998, 10:585-587.

18. Saleh MM, Glombitza KW: Volatile Oil of Marrubium vulgare and its Antischistosomal Activity. Planta Med 1989, 55:105-108.

19. Morteza-Semnani K, Saeedi M: The Essential Oil Composition of Marrubium astracanicum Jacq. From Iran. J Essent Oil Bearing Plants 2004 7:239-242.

20. Asadipour A, Mehrabani M, Nazeri V, Tabarraii M: Composition of the essential oil of Marrubium vulgare L. Ulum-i-Daroei 2005, 2:77-82

21. Khanavi M, Ghasemian L, Hosseiny Motlagh E, Hadjiakhoondi A, Shafiee A: Chemical Composition of The Essential Oils of Marrubium parviflorum Fisch. \& C.A. Mey and Marrubium vulgare L. from Iran. Flav Fragr J 2005, 20:324-326.

22. Voravuthikunchai SP, Sririrak T, Limsuwan S, Supawita T, lida T, Honda T: Inhibitory effects of active compounds from Punica granatum pericarp on Verocytotoxin by enetrohaemorrhagic Escherichia coli 0157: H7. J Health Sci 2005, 51(5):590-596.

23. Burt S: Essential oils: their antibacterial properties and potential applications in foods. International Journal of Food Microbiology 2004, 94:223-253.

24. Berghe VA, Vlietinck AJ: Screening methods for antibacterial and antiviral agents from higher plants. Method for Plant Biochemistry 1991, 6:47-68.

25. Wade $D$, Silveira A, Rollins-Smith L, Bergman T, Silberring J, Lankinen $\mathrm{H}$ : Hematological and antifungal properties of temporin $A$ and a cecropin A-temporin A hybrid. Acta Biochim Pol 2001, 48:1185-1189.

26. Pérez C, Agnese AM, Cabrera JL: The essential oil of Senecio graveolens (Compositae): chemical composition and antimicrobial activity tests. $J$ Ethnopharmacol 1999, 66:91-96.

27. Bagamboula CF, Uyttendaele M Debevere J: Acid tolerance of Shigella sonnei and Shigella flexneri. J Appl Microbiol 2002, 93(3):479-486.

28. Saïdana D, Mahjoub S, Boussaada O, Chriaa J, Mahjoub MA, Chéraif I, Daami M, Mighri Z, Helal AN: Antibacterial and Antifungal Activities of the Essential Oils of two Saltcedar Species from Tunisia. J Am Oil Chem Soc 2008, 85(9):817-826.

29. Hichri F, Ben Jannet H, Cheriaa J, Jegham S, Mighri Z: Antibacterial activities of a few prepared derivativesof oleanolic acid and of other natural triterpenic compounds. CR Chim 2003, 6:473-483.

30. Bel Haj Khether F, Ammar S, Saidana D, Daami-Remadi M, Cheriaa J, Liouane K, Mahjoub MA, Helal AN, Mighri Z: Chemical composition, 
antibacterial and antifungal activities of Trichoderma sp. growing in Tunisia. Annals of Microbiology 2008, 58:303-308.

31. May J, Chan CH, King A, Williams L, French GL: Time-kill studies of tea tree oils on clinical solates. J Antimicrobial Chemoter 2000, 45:639-643.

32. Ferreira A, Proenca AC, Serralheiro CMLM, Araujo MEM: The in vitro screening for acetylcholinesterase inhibition and antioxidant activity of medicinal plants from Portugal. J Ethnopharmacology 2006, 108:31-37.

33. Saidana D, Mahjoub MA, Boussaada O, Chriaa J, Cheraif I, Daami-Remadi M, Mighri Z, Helal AN: Chemical composition and antimicrobial activity of volatile compounds of Tamarix boveana (Tamaricaceae). Microbiology Res 2008, 163:445-455.

34. Boussaada O, Ammar S, Saidana D, Chriaa J, Chraif I, Daami-Remadi M, Helal AN, Mighri Z: Chemical composition and antimicrobial activity of volatile components from capitula and aerial parts of Rhaponticum acaule DC growing wild in Tunisia. Microbiology Res 2008, 163:87-95.

35. Hammer KA, Carson CF, Riley TV: Antimicrobial activity of essential oils and other plant extracts. J App Microbiology 1999, 86:985-990.

36. Delaquis PJ, Stanich K, Girard B, Mazza G: Antimicrobial activity of individual and mixed fractions of dill, cilantro, coriander and eucalyptus essential oils. Int J Food Microbiology 2002, 74:101-109.

37. Omar-Hamza JM, Carolien JP, Van Den Bout-van Den Beukel, MeckyMatee IN, Paul-Verweij JAME: Antifungal activity of some Tanzanian plants used traditionally for the treatment of fungal infections. J Ethnopharmacology 2006, 108:124-132.

38. Lopez P, Sanchez C, Batlle R, Nerin C: Solid- and vapor-phase antimicrobial activities of six essential oils: susceptibility of selected foodborne bacterial and fungal strains. Journal of Agricultural and Food Chemistry 2005, 53:6939-6946.

39. Ceylan E, Fung DYC: Antimicrobial activity of spices. Journal of Rapid Methods and Automation in Microbiology 2004, 12:1-55.

40. Zhao WH, Hu ZO, Okubo S, Hara Y, Shimamura T: Mechanism of synergy between epigallocatechin gallate and $\beta$-lactams against methicillinresistant Staphylococcus aureus. Antimicrob. Agents Chemother 2001, 45:1737-1742.

41. Cal K: Skin penetration of terpenes from essential oils and topical vehicles. Planta Med 2006, 72:311-316.

42. Oyedeji O, Afolayan A: Comparative study of the essential oil composition and antimicrobial activity of Leonotis leonurus and $L$. ocymifolia in the Eastern Cape. African J Bot 2005, 71:114-116.

43. Cakir $\mathrm{A}$, Kordali $\mathrm{S}$, Zengin $\mathrm{H}$, Izumi $\mathrm{S}$, Hirata : Composition and antifungal activity of essential oils isolated from Hypericum hyssopifolium and Hypericum heterophyllum. Flavour Frag J 2004, 19:62-68.

44. Nada B, Mirjana S, Valerija D: Phytochemical composition and antimicrobial activity of Satureja montana L. and Satureja cuneifolia Ten. essential oils. Acta Bot Croat 2005, 64:313-322.

45. Cimanga K, Kambu K, Tona L, Apers S, De Bruyne T, Hermans N, Totte J, Pieters L, Vlietinck AJ: Correlation between chemical composition and antibacterial activity of essential oils of some aromatic medicinal plants growing in the Democratic Republic of Congo. J Ethnopharmaco 2002, 79:213-220

46. Picaud S, Olsson ME, Brodelius M, Brodelius PE: Cloning, expression, purification and characterization of recombinant (+)- germacrene $D$ synthase from Zingiber officinale. Arch Biochem Biophys 2006, 452:17-28.

47. Sahin F, Gulluc M, Daferera D, Sokmen A, Sokmen M, Polissiou M, Agar G, Ozer $\mathrm{H}$ : Biological activities of the essential oils and methanol extract of Origanum vulgare ssp. vulgare in the eastern Anatolia region of Turkey. Food Control 2004, 15:549-557.

48. Sylvestre M, Legault J, Dufour D, Pichette A: Chemical composition and anticancer activity of leaf essential oil of Myrica gale L. Phytomedicine 2005, 12:299-304.

49. Burke YD, Stark MJ, Roach SL, Sen SE, Crowell PL: Inhibition of pancreatic cancer growth by the dietary isoprenoids farnesol and geraniol. Lipids 1997, 32:151-156.

50. Setzer WN, Schmidt JM, Noletto JA, Vogler B: Leaf oil compositions and bioactivities of abaco bush medicines. Pharmacology online 2006, 3:794-802

51. Hou J, Sun T, Hu J, Chen SY, Cai XQ, Zou GL: Chemical composition, cytotoxic and antioxidant activity of the leaf essential oil of Photinia serrulata. Food Chem 2007, 103:355-358.
doi:10.1186/1476-511X-10-161

Cite this article as: Zarai et al:: The in-vitro evaluation of antibacterial, antifungal and cytotoxic properties of Marrubium vulgare L. essential oil grown in Tunisia. Lipids in Health and Disease 2011 10:161.

\section{Submit your next manuscript to BioMed Central and take full advantage of:}

- Convenient online submission

- Thorough peer review

- No space constraints or color figure charges

- Immediate publication on acceptance

- Inclusion in PubMed, CAS, Scopus and Google Scholar

- Research which is freely available for redistribution

Submit your manuscript at www.biomedcentral.com/submit
Biomed Central 